\title{
Occurrences of Ornithocoris toledoi (Cimicidae) on a free-range chicken farm in the state of Rio de Janeiro, Brazil
}

\author{
Ocorrência de Ornithocoris toledoi (Cimicidae) em uma fazenda com criação rústica de galinhas no \\ estado do Rio de Janeiro, Brasil
}

\author{
Marcus Sandes Pires ${ }^{1 *}$; Hermes Ribeiro Luz ${ }^{2}$; Maristela Peckle ${ }^{3}$; Claudia Bezerra da Silva ${ }^{4}$; \\ Gabriela Lopes Vivas Vitari ${ }^{5}$; Renata Lins da Costa ${ }^{5}$; Mariana Guimarães Graciosa ${ }^{6}$; Huarrisson Azevedo Santos ${ }^{4}$; \\ João Luiz Horacio Faccini ${ }^{3}$; Carlos Luiz Massard ${ }^{3}$
}

\begin{abstract}
${ }^{1}$ Núcleo de Animais de Laboratório, Pró-reitoria de Pesquisa e Pós-graduação e Inovação, Universidade Federal Fluminense - UFF, Niterói, RJ, Brasil

${ }^{2}$ Departamento de Medicina Veterinária Preventiva e Saúde Animal, Faculdade de Medicina Veterinária e Zootecnia, Universidade de São Paulo - USP, São Paulo, SP, Brasil

${ }^{3}$ Departamento de Parasitologia Animal, Instituto de Veterinária, Universidade Federal Rural do Rio de Janeiro - UFRRJ, Seropédica, RJ, Brasil

${ }^{4}$ Departamento de Epidemiologia e Saúde Pública, Instituto de Veterinária, Universidade Federal Rural do Rio de Janeiro - UFRRJ, Seropédica, RJ, Brasil

5 Programa de Pós-graduação em Ciências Veterinárias, Instituto de Veterinária, Universidade Federal Rural do Rio de Janeiro UFRRJ, Seropédica, RJ, Brasil

${ }^{6}$ Departamento de Produção Animal, Faculdade de Medicina Veterinária, Centro de Ensino Superior de Valença - CESVA, Valença, RJ, Brasil
\end{abstract}

Received November 27, 2017

Accepted April 6, 2018

\begin{abstract}
Ornithocoris toledo $i$ is a hematophagous insect that parasites birds, particularly, galliformes. Although the occurrence of this arthropod is relatively low in Brazil, this is an important ectoparasite associated with backyarding poultry. The objective of this study was to report the occurrence of $O$. toledo $i$ in a free-range chicken farm in the state of Rio de Janeiro, Brazil, including aspects of its taxonomic identification, biology and epidemiology.
\end{abstract}

Keywords: Bed bugs, chicken bugs, ectoparasite, Gallus gallus, poultry.

\section{Resumo}

Ornithocoris toledoi é um inseto hematófago que parasita aves, particularmente os galiformes. Embora a ocorrência deste artrópode seja relativamente baixa no país, este é um ectoparasito importante relacionado à criação rústica de galinhas. $\mathrm{O}$ objetivo estudo foi relatar a ocorrência de $O$. toledoi em uma criação rústica de galinhas no estado do Rio de Janeiro, incluindo aspectos sobre a sua identificação taxonômica, biologia e epidemiologia.

Palavras-chave: Percevejos, percevejos-de-galinha, ectoparasita, Gallus gallus, produção avícola.

Cimicids are hematophagous insects of small size, ranging from $4.5 \mathrm{~mm}$ to $7 \mathrm{~mm}$ (FREITAS et al., 1978). The original description (PINTO, 1927) was based on absence of wings, pronotum with rounded edges and anterior margins presenting little depth, narrower than the rear margin, with a trapezoidal appearance and body covered with small short bristles. The Cimicidae include six subfamilies, 24 genera and 110 species (HENRY, 2009) and are mainly distributed in the Neotropical region. "Bed bug" is the

*Corresponding author: Marcus Sandes Pires. Núcleo de Animais de Laboratório - NAL, Pró-reitoria de Pesquisa de Pós-graduação e Inovação PROPPI, Universidade Federal Fluminense - UFF, Av. Morro do Valonguinho, s/n, CEP 24240-210, Niterói, RJ, Brasil. e-mail: marcussandes@yahoo.com.br popular name given to the members of this family for which the life cycle includes egg, nymph and adult stages. These insects are temporary ectoparasites and, between blood meals, they remain in their hosts' nests or in the cracks or crevices of their hosts' shelters (USINGER, 1966). Most cimicid species are parasites of birds and bats, but some are parasites of humans and are therefore of public health concern (COSTA LIMA, 1940; FORATTINI, 1990).

Some species of the genera Cimex Linnaeus, 1758, Ornithocoris Pinto, 1927; Propicimex Barber, 1941; and Latrocimex Lent, 1941, have been found in Brazil (RYCKMAN et al., 1981). The genus Ornithocoris currently has two valid species: O. toledoi and Ornithocoris pallidus Usinger, 1959. Both species are apparently rare in Brazil. Ornithodoros toledoi has been reported 
twice on poultry farms in the states of São Paulo (PINTO, 1927) and Minas Gerais (CARVALHO, 1939). It has also been found infesting chickens in other South American countries, such as Bolivia and Argentina (RYCKMAN et al., 1981). Although there is one report of the genus Ornithocoris in the state of Rio Grande do Sul (OTTO et al., 2008), its identification was questioned by Di Iorio et al. (2010). The species $O$. pallidus was described from the nests of Pygochelidon cyanoleuca (Vielliot, 1817) (Aves: Passeriformes) in Viçosa, state of Minas Gerais, Brazil. Later on, it was reported in the states of Florida and Georgia, USA, associated with chickens and Passeriform birds: Progne subis Linnaeus, 1758, and Passer domesticus Linnaeus, 1758 (USINGER, 1966; WILSON et al., 1986). In relation to the distribution of $O$. toledo $i$ in chicken farms in Brazil, few reports have been observed so far (PINTO, 1927; MORAES, 1939; CARVALHO, 1939). However, their presence may lead to a decrease in egg production and increase in susceptibility to diseases (CARVALHO, 1939; SNIPES et al., 1940). This aspect related to a free-range chicken breeding can cause losses up to the abandon of this activity. Another important aspect is related to its biology, as this parasite was observed in nests of wild birds (CARPINTERO et al., 2011), which demonstrates it has a greater potential of dissemination to other localities.

This study aimed to report the occurrence of $O$. toledo $i$ to a farm located in the municipality of Valença (220 14' 44" S; $\left.43^{\circ} 42^{\prime} 01^{\prime} \mathrm{W}\right)$, state of Rio de Janeiro, Brazil (Figure 1) and to add biological, morphologic and epidemiological information about this hematophagous species which is of importance to free-range chicken farms and wild birds." This farm was primarily set up for milk production, but also raises backyarding poultry such as Gallus gallus, Meleagris gallopavo, Coturnix coturnix and Numida meleagris (Figures 2A, 2B). During a technical visit in March 2012, high levels of infestation with small dark wingless insects were observed in the nests inside the chicken coops, in cracks in the walls and roof, and on the birds' food and fecal waste (Figure 2D). Some chickens were also inspected for signs of parasitism (Figure 2C).

Some specimens were collected and placed in polypropylene tubes containing $70 \%$ alcohol. These were then transported to the Multiuser Microscopy and Bioimaging Laboratory of the Federal Rural University of Rio de Janeiro (UFRRJ). Eight specimens were cleared in lactophenol at $37^{\circ} \mathrm{C}$ and mounted in Hoyer's medium. An optical microscope was used at 1800 s, 400x and $1000 \mathrm{x}$ to make the following measurements of body parts: pronotum length(PL); pronotum width (PW); second and third bristles of the posterior pronotum angle (Lb2 and Lb3); first, second, third and fourth antennal flagella (A1, A2, A3 and A4); head width with eyes (HW); PW/HW ratio; interocular space (IS); length of the male genitalia (GL); abdomen length (AL) and width (AW); hemelytra length $(\mathrm{HmL})$ and width $(\mathrm{HmW})$; length of the femur (FL) and tibia (TiL) of the third leg; and total length (TL) of the specimen (Figure 3A).

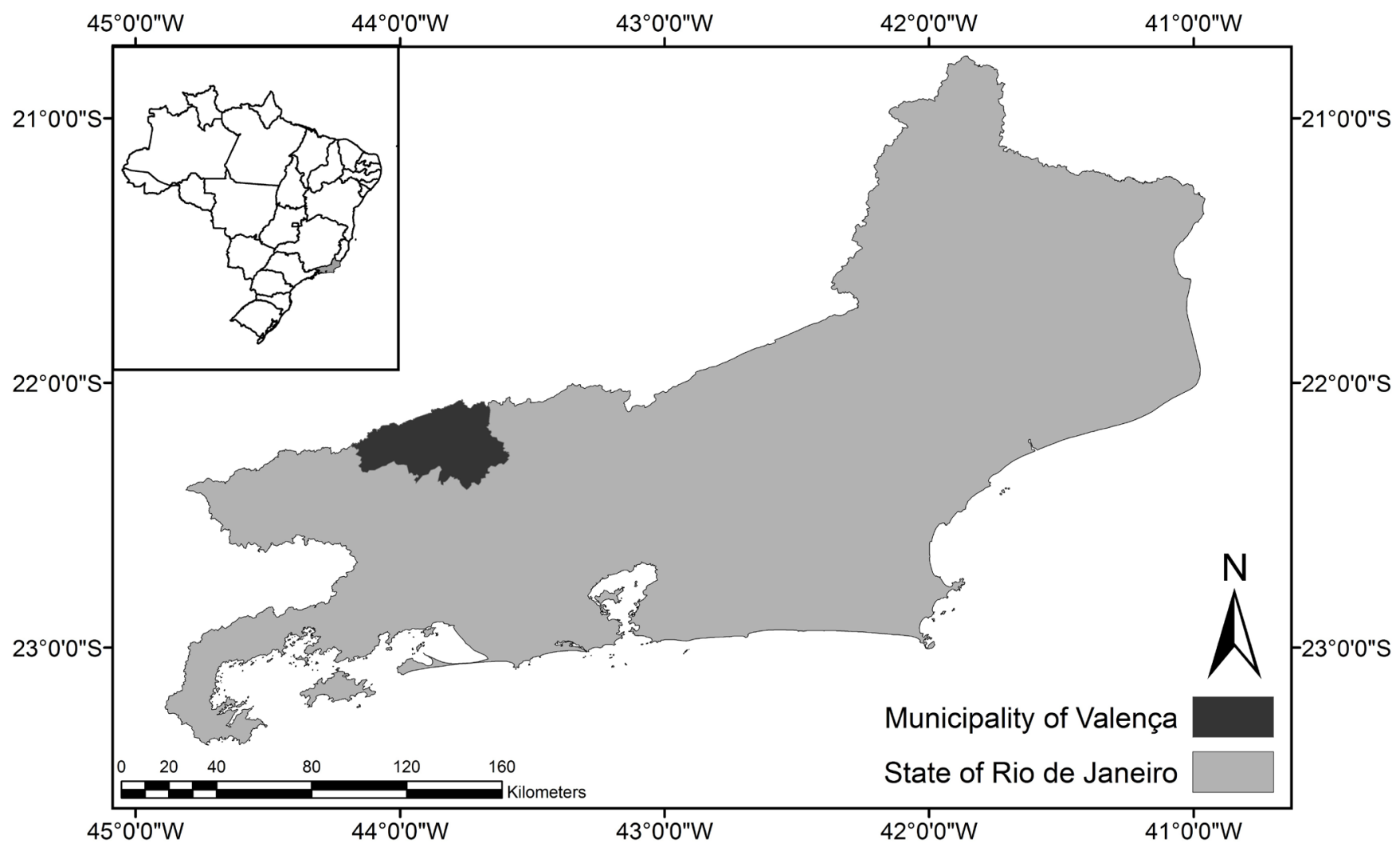

Figure 1. Geographical location of the area where specimens of Ornithocoris toledoi were observed in free-range chicken farm, in March 2012, in the state of Rio de Janeiro, Brazil. 


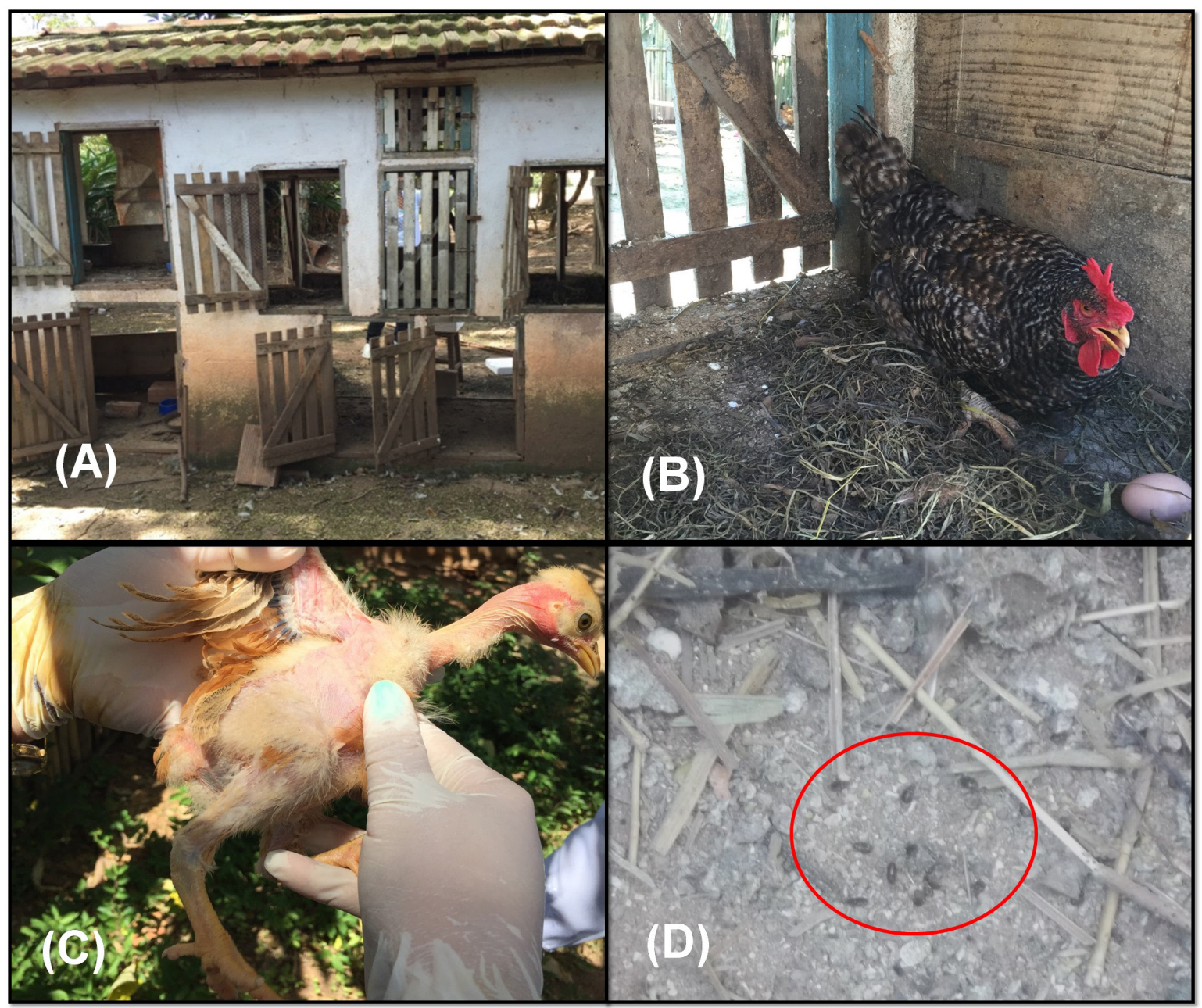

Figure 2. View of the chicken coops (A and B). Examination of chickens (C). Ornithocoris toledoi seen on the ground in the coop (D).

All of the measurements were made using the CellD software, version 5.1, under an OLYMPUS BX51 microscope. We compared our specimens with two reference specimens of $O$. toledo $i$ in the Costa Lima Entomological Collection of the Oswaldo Cruz Institute (IOC/FIOCRUZ; accession numbers CCL 5475, slide 4730, female specimen, and CCL 5476, slide 4731, male specimen). Two voucher specimens (female and male) were deposited in the "Angelo Moreira da Costa Lima" Entomological Collection (CECL) of the Biology Institute, Federal Rural University of Rio de Janeiro (accession numbers 12501 and 12502, respectively). We identified our specimens in accordance with Pinto (1927), Carvalho (1939), Moraes (1939), Usinger (1959, 1966), Jansen (1979), Jurberg \& Azevedo (1982) and Di Iorio et al. (2010).

During the technical visit, we observed that these insects moved quickly to hidden in dark crevices and cracks of buildings. Regarding to the chickens, some of them showed signs of weakness, which can be directly related to the high infestation level that was observed in the flock. The presence of this ectoparasite in chicken coops can decrease egg production and increase susceptibility to other diseases (CARVALHO, 1939). Although some studies have indicated that pathogen transmission by other Cimicidae species occurs (BURTON, 1963; DELAUNAY, 2012; LEULMI et al., 2015), the role of $O$. toledo $i$ as a vector of pathogens to chickens is unknown.

Also during the technical visit to the farm, we did not see any evidence of the presence of insects in the bodies of chickens, or any lesions suggestive of parasitism by these insects. However, Carvalho (1939) and Snipes et al. (1940) reported that the signs caused by the bites of $O$. toledoi in G. gallus consisted of punctiform hemorrhage and hyperemia at the bite sites, and that they disappeared almost entirely within 12 hours. This may have the cause of the lack of signs in the birds during our visit. In addition, the owner of the farm reported deaths of young chickens, probably due to blood loss resulting from the high of infestation by these insects, which feed during all phases of their life cycle (USINGER, 1966).

Accordingly, identification of $O$. toledo $i$ was based on the following characters: pronotum wider than long (Figure 3C); second segment, of the antenna wider than the third and fourth ones; presence of two pairs of bristles in the posterior prothoracic angles (Lb2 and Lb3) (Figure 3D); presence of two tufts in the final thirds of tibia I and II in males, and only in tibia II in females 


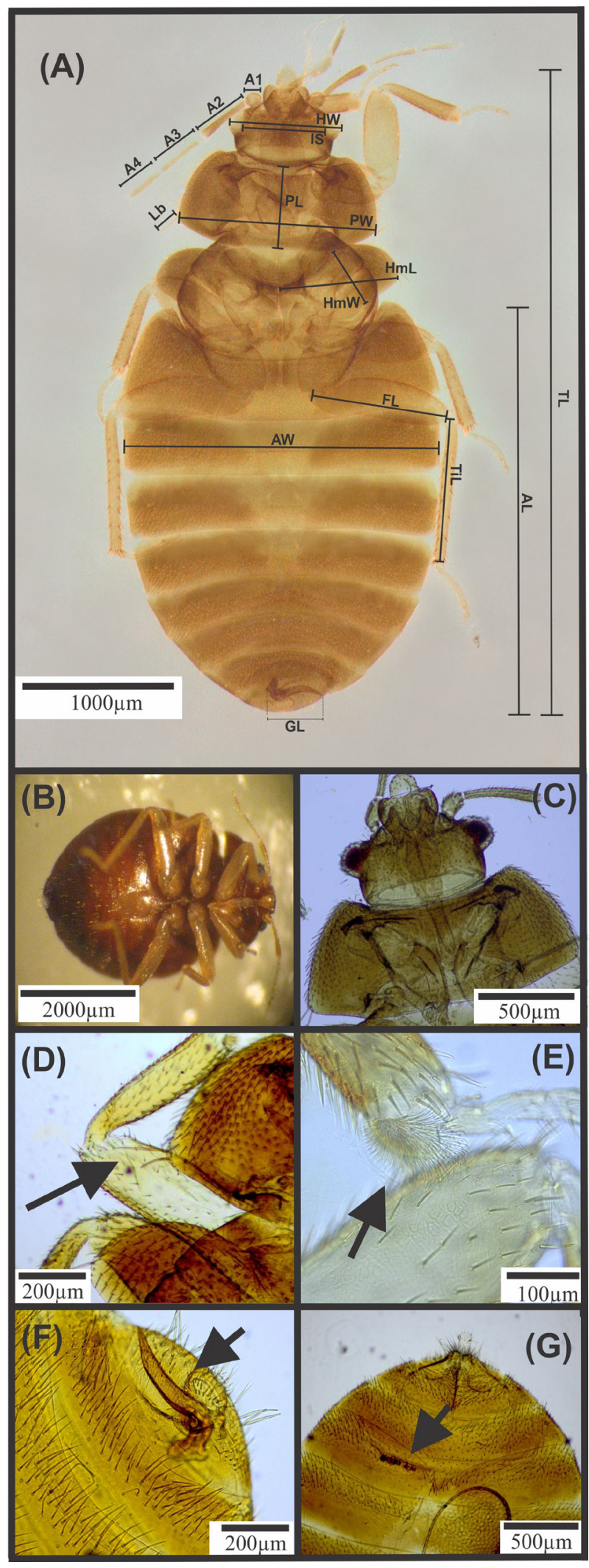

Figure 3. Morphology of Ornithocoris toledoi collected on the farm. Parameter scheme measurements of the $O$. toledoi specimens (A); O. toledoi observed under stereomicroscope, showing dark brown color (B); Pronotum of O. toledoi wider than long (C); Details pointed with an arrow: pronotum bristles (D); Bristle tufts in the final third of the tibia (E); Sexual organ of the male (F) and female $(\mathrm{G})$.
(Figure 3E); presence of spicule in males; presence of Ribaga's organ in the dorsal region of in females (Figure $3 \mathrm{~F}$ and $3 \mathrm{G}$ ). These external characters of the genitalia are typical of $O$. toledo $i$ (JANSEN, 1979; JURBERG \& AZEVEDO, 1982). As expected, these measurements varied between the specimens collected (Table 1) and among specimens of $O$. toledoi from other regions (PINTO, 1927; CARVALHO, 1939; MORAES, 1939; USINGER, 1966; JANSEN, 1979; DI IORIO et al. 2010). Morphometric variations may be influenced by the specimen's physiological status, adaptive changes, genetic differences (DUJARDIN \& SLICE, 2007), feeding or climatic conditions (JANSEN, 1979).

Despite the morphological similarities between $O$. toledo $i$ and $O$. pallidus, they can be separated by the dark-brown body (Figure 3B), which is typical of $O$. toledoi (CARVALHO, 1939; JANSEN, 1979; MORAES, 1939; PINTO, 1927), and the ratio between the width and pronotum head width (PW/HW) proposed by Usinger (1966). In the specimens collected by us, this ratio (PW/HW) was approximately 1.8, matching the diagnosis of O. toledoi by Usinger (1966) and Di Iorio et al. (2010).

Regarding insect/host relationships, specimens were collected from chickens, thus confirming the association of this species with this typical host (CARVALHO, 1939; MORAES, 1939; PINTO, 1927). Recently, the species $O$. toledo $i$ was also described from nests of birds Psittacidae (CARPINTERO et al., 2011), which suggests that this species may use wild birds as hosts, but further research is needed to clarify this issue.

Two years after the first technical visit, these ectoparasites were no longer observed in the chicken coops, probably due to the effective chemical control recommended to the farmer.

Table 1. Mean values obtained from morphometry on Ornithocoris toledoi in this study.

\begin{tabular}{lcc}
\hline \multicolumn{1}{c}{ Body parts } & M $(\mathbf{n}=\mathbf{4})$ & F $(\mathbf{n}=\mathbf{4})$ \\
\hline Head width (HW) & $761.8 \pm 29.3$ & $811.5 \pm 34.9$ \\
Interocular space (IS) & $549.4 \pm 28.5$ & $582.4 \pm 25.0$ \\
Pronotum width (PW) & $1360.9 \pm 31.0$ & $1429.4 \pm 63.0$ \\
Pronotum length (PL) & $484.2 \pm 12.6$ & $513.1 \pm 15.2$ \\
Ratio PW/HW' & $1.8 \pm 0.01$ & $1.8 \pm 0.02$ \\
Bristle length2 (Lb2) & $196.1 \pm 2.6$ & $154.2^{\mathrm{a}}$ \\
Bristle length3 (Lb3) & $134.7^{\mathrm{a}}$ & $130.5 \pm 22.4$ \\
Antennal segment I (A1) & $120.1 \pm 10.6$ & $152.3^{\mathrm{a}}$ \\
Antennal segment II (A2) & $370.7^{\mathrm{a}}$ & $396.4^{\mathrm{a}}$ \\
Antennal segment III (A3) & $326.4^{\mathrm{a}}$ & $*$ \\
Antennal segment IV (A4) & $320.5^{\mathrm{a}}$ & $*$ \\
Male genitalia length (GL) & $423.2 \pm 37.9$ & - \\
Total length (TL) & $3890.8 \pm 62.6$ & $4167.0 \pm 162.8$ \\
Abdomen lenght (AL) & $2134.9 \pm 115.0$ & $2425.2 \pm 103.6$ \\
Abdomen width (AW) & $2047.4 \pm 58.2$ & $2078 \pm 81.7$ \\
Hemelytra length (HmL) & $421.7 \pm 13.0$ & $460.6 \pm 25.9$ \\
Hemelytra width (HmW) & $778.3 \pm 21.1$ & $877.1 \pm 48.3$ \\
Femur length (3 ${ }^{\circ}$ paw)(FL) & $897.7 \pm 84.3$ & $895.1^{\mathrm{a}}$ \\
Tibiaelength (3 ${ }^{\circ}$ paw)(TiL) & $970.9 \pm 56.3$ & $1066.5^{\mathrm{a}}$ \\
\hline
\end{tabular}

$\mathrm{M}=$ Male; $\mathrm{F}=$ Female; $\overline{\mathrm{X}}_{ \pm} \mathrm{SD}$; ${ }^{*}$ Not measured; ${ }^{\mathrm{a}}$ Values from a single specimen. 


\section{Acknowledgements}

Dra. Jane Costa, curator of the Entomological Collection of the Oswaldo Cruz Institute (FIOCRUZ) and Msca. Claudia Leal Rodrigues, assistant curator (FIOCRUZ), and Dra. Teresa Cristina Gonçalves, Department of Entomology (FIOCRUZ), for the technical assistance. The CNPq and FAPERJ, for research scholarships granted to João Luiz Horácio Faccini and Carlos Luiz Massard.

\section{References}

Burton GJ. Bedbugs in relation to transmission of human diseases. Public Health Rep 1963; 78(6): 513-524. http://dx.doi.org/10.2307/4591852. PMid:14017240.

Carpintero D, Berkunsky I, Aramburú R. Primer registro del Calancate Común Aratinga a. acuticaudata (Aves: Psittacidae) como huésped nativo primario de Ornithocoris toledoi Pinto (Hemiptera: Heteroptera: Cimicidae). Rev Mus Argent Cienc Nat 2011; 13(2): 205-212. http:// dx.doi.org/10.22179/REVMACN.13.223.

Carvalho JCM. Sobre a biologia do Ornithocoris toledoi Pinto 1927, percevejo dos galinheiros em Minas Gerais (Hemíptera: Cimicidae). Ceres 1939; 1: 128-140.

Costa Lima AMC. Superfamília Cimicoidea. In: Costa Lima AMC, editor. Insetos do Brasil. 3th ed. Rio de Janeiro: Escola Nacional Agronomia; 1940. p. 242-292. (Série Didática).

Delaunay P. Human travel and traveling bedbugs. J Travel Med 2012; 19(6): 373-379. http://dx.doi.org/10.1111/j.1708-8305.2012.00653.x. PMid:23379708.

Di Iorio O, Turienzo P, Masello J, Carpintero DL. Insects found in birds'nests from Argentina. Cyanoliseus patagonus (Vieillot, 1818) [Aves: Psittacidae], with the description of Cyanolicimex patagonicus, gen. n., sp. n., and a key to the genera of Haematosiphoninae (Hemiptera: Cimicidae). Zootaxa 2010; 2728: 1-22.

Dujardin JP, Slice DE. Contributions of morphometrics to medical entomology. In: Tibayrenc M, editor. Encyclopedia of infectious diseases: modern methodologies. New York: Wiley \& Sons; 2007. p. 435-447. http://dx.doi.org/10.1002/9780470114209.ch25.

Forattini OP. Os Cimicídeos e sua importância em Saúde Pública (HemipteraHeteroptera; Cimicidae). Rev Saúde Pública 1990; 24(Suppl): 1-37. http://dx.doi.org/10.1590/S0034-89101990000700001. PMid:2218370.
Freitas MG, Costa HMA, Costa JO, Lide P. Ordem Hemiptera: Famílias Reduviidae e Cimicidae. In: Freitas MG, Costa HMA, Costa JO, Lide P, editors. Entomologia e acarologia médica e veterinária. 4th ed. Belo Horizonte: Precisa; 1978. p. 175-191.

Henry TJ. Biodiversity of Heteroptera. In: Foottit RG, Adler PH, editors. Insect biodiversity: science and society. Oxford: Wiley-Blackwell Publishing; 2009. p. 223-263. http://dx.doi.org/10.1002/9781444308211.ch10.

Jansen AM. Estudos biológicos e biométricos de Ornithocoris toledoi Pinto, 1927 (Cimicidae: Hemiptera) [dissertation]. Rio de Janeiro: Universidade Federal Rural do Rio de Janeiro; 1979.

Jurberg J, Azevedo EMVM. Contribuição para o estudo da morfologia de Ornithocoris toledoi Pinto, 1927 (Hemiptera, Cimicidae). Rev Bras Biol 1982; 42(1): 255-262.

Leulmi H, Bitam I, Berenger JM, Lepidi H, Rolain JM, Almeras $\mathrm{L}$, et al. Competence of Cimex lectularius Bed bugs for the transmission of Bartonella quintana, the Agent of Trench Fever. PLoS Negl Trop Dis 2015; 9(5): e0003789. http://dx.doi.org/10.1371/journal.pntd.0003789. PMid:26000974.

Moraes RG. Breve nota sobre o Ornithocoris toledoi Pinto,1927. Rev Med Cirurg Brasil 1939; 47(2): 250-255.

Otto MA, Silva AS, Zanette RA, Schmitt L, Monteiro SG. Infestação por Ornithocoris sp. em residências do Município de Santa Maria, Rio Grande do Sul, Brasil. Rev Bras Parasitol Vet 2008;17(Suppl 1): 99-101. PMid:20059826.

Pinto C. Ornithocoris toledoi, novo gênero e nova espécie de percevejo de ave (Hemiptera - Fam. Cimicidae). Rev Biol Hyg 1927; 1: 17-22.

Ryckman RE, Bentley DG, Archbold EF. The Cimicidae of the Americas and Oceanic islands, a checklist and bibliography. Bull Soc Vec Ecol 1981; 6: 93-142.

Snipes BT, Carvalho JCM, Tauber OE. Biological studies of Ornithocoris toledoi Pinto, the Brazilian chicken bedbug. Iowa State Coll J Sci 1940; 15: 27-36.

Usinger RL. New species of Cimicidae (Hemiptera). Entomol 1959; 92: 218-222.

Usinger RL. Monograph of Cimicidae (Hemiptera - Heteroptera). Maryland: Entomological Society of America, College Park; 1966. (Serie Thomas Say Foundation ).

Wilson N, Smith GC, Sykes DL. An additional record of Ornithocoris pallidus (Hemiptera: Cimicidae) for the United States. J Med Entomol 1986; 23(5): 575. http://dx.doi.org/10.1093/jmedent/23.5.575. PMid:3772958. 